\title{
STRATEGI PELAYANAN MISI DIMASA PANDEMI CORONAVIRUS DISEASE 2019
}

\author{
Adieli Waruwu ${ }^{1 *}$, Samuel Purdaryanto ${ }^{2}$ \\ Sekolah Tinggi Teologi Berita Hidup ${ }^{1}$ \\ Sekolah Tinggi Teologi Arastamar Bengkulu \\ *)Email Correspondence: adieli.waruwu@hotmail.com
}

Abstract: $\quad$ At the end of 2019, the whole world and Indonesia were shocked by the emergence of the new coronavirus disease 2019. It has been more than a year since this disaster struck. The number of victims around the world has reached more than one hundred million with the death toll of more than two million people. Various efforts have been made to prevent the spread of this virus, one of which is social restrictions so that it has an impact in various areas of human life. One of the impacts is the missionary service which usually carries out social and face-to-face interactions. By using qualitative research methods with a literature review approach, observation, and interviews and then describing, this study will provide answers and solutions for mission service strategies during the Covid19 pandemic. The results of this study found answers to mission services online or online. By utilizing internet networks and social media, the gospel can still be preached despite social restrictions. Facebook, YouTube, Instagram, and Tiktok are some social media applications that can be used for mission services during the Covid-19 pandemic, through these applications this news can be presented in the form of writing, audio, and video which are shared via social media. This strategy, with its strengths and weaknesses, provides a great opportunity to continue working on the Great Commission of the Lord Jesus during the Covid-19 pandemic.

Keywords: $\quad$ Missions, evangelism, COVID-19 pandemic, social media.

Abstrak: $\quad$ Akhir tahun 2019 seluruh dunia dan Indonesia dikejutkan dengan kemunculan wabah baru coronavirus disease 2019. Sudah lebih setahun bencana ini menyerang. Korban diseluruh dunia sudah mencapai lebih dari seratus juta dengan korban meninggal lebih dari dua juta orang. Berbagai upaya dilakukan untuk mencegah penyebaran virus ini, salah satunya adalah pembatasan social, sehingga memberikan dampak dalam berbagai bidang kehidupan manusia. Salah satu dampaknya adalah pelayanan misi yang biasa melakukan interaksi sosial dan tatap muka. Dengan menggunakan metode penelitian kualitatif dengan pendekatan kajian pustaka, pengamatan dan wawancara lalu mendeskripsikan, penelitian ini akan memberikan jawaban dan solusi bagi strategi pelayanan misi dimasa pandemi covid19. Hasil dari penelitian ini menemukan jawaban pelayanan misi secara daring atau online, Dengan memanfaatkan jaringan internet dan media sosial, Injil tetap dapat diberitakan meskipun terjadi pembatasan sosial. Facebook, YouTube, Instagram dan Tiktok adalah beberapa aplikasi media sosial yang dapat digunakan untuk pelayanan misi dimasa pandemi covid-19, melalui aplikasi tersebut berita Inil dapat disajikan dalam bentuk tulisan, audio dan video yang dibagikan melalui media sosial. Strategi ini, dengan kekuatan dan kelemahannya, memberikan peluang yang besar untuk tetap mengerjakan Amanat Agung Tuhan Yesus pada masa pandemi covid-19.

Kata kunci: Pelayanan misi, pekabaran Injil, pandemi covid-19, media sosial. 


\section{PENDAHULUAN}

Sudah lebih dari setahun dunia menghadapi bencana yang disebut dengan coronavirus disease19. Hingga artikel ini ditulis, jumlah kasus covid-19 diseluruh dunia suadah mencapai 109.068.797 dengan korban meninggal dunia 2.403.365. ${ }^{1}$ Memperhatikan situasi yang ada, kemungkinan penambahan jumlah kasus baru akan selalu ada. Untuk menekan penyebaran virus, diawal pandemi banyak negara yang mengambil kebijakan melakukan karantina wilayah, menghentikan beberapa aktivitas yang mengundang kerumunan banyak orang guna menghindari kontak. Kebijakan ini tentunya berdampak kepada banyak hal, mulai dari bisnis, pendidikan, kehidupan bergereja dan sosialisasi dalam masyarakat.

Indonesia sebagai salah satu negara di dunia yang terdampak bencana non alam covid-19, juga berupaya melakukan pencegahan penyebaran virus melalui kebijakan yang diambil oleh pemerintah selaku pemangku kepentingan. Pembatasan Sosial Bersekala Besar (PSBB) merupakan upaya yang dilakukan pemerintah Indonesia untuk pencegahan penyebaran virus covid-19. Pembatasan dilakukan pada sektor ekonomi, sosial dan juga pendidikan. Menurut Wijaya dan rekan, upaya pembatasan sosial bersekala besar ini tidak hanya menyasar sektor sosial ekonomi dan pendidikan, namun juga pada sektor keagamaan. ${ }^{2}$ Tidak dapat dipungkiri, hal ini sangat berdampak bagi masyarakat Indonesia dan juga perekonomiannya.

\footnotetext{
1 Nur Rohmi Aida, "Update Corona Dunia 14 Februari: 109 Juta Kasus Dunia," Kompas, t.t., https://www.kompas.com/tren/read/2021/02/14/083400665/update-corona-dunia-14-februari--109-juta-kasuscovid-19-optimisme-boris?page=all.

2 Fransiskus Irwan Wijaya dkk., "MENSTIMULASI PRAKTIK GEREJA RUMAH DI TENGAH PANDEMI COVID-19," Kurios: Jurnal Teologi Dan Pendidikan Kristen 6, no. 1 (2020): 127-39, https://doi.org/10.30995/kur.v6i1.166.
} 
Pembatasan sosial pada sektor keagamaan membuat sebagian gereja merubah model ibadah dari berkumpul dengan tatap muka, menjadi daring atau virtual. Mengenai hal ini, Silitonga menulis sebuah penelitian mengenai respon gereja terhadap pandemi covid-19, yang memaparkan tentang orang Kristen yang beribadah di rumah dengan tuntunan dari gereja. ${ }^{3}$ Hal ini merupakan wujud respon yang baik, meskipun ada pembatasan namun ada solusi atau cara agar tetap dapat beribadah kepada Tuhan. Selain ibadah daring atau virtual, solusi lainnya adalah dengan menstimulasi praktek gereja rumah sebagaimana dituliskan dalam penelitian Wijaya dan rekan. ${ }^{4}$

Sebagai institusi, gereja merespon cukup baik dalam menghadapi pandemi covid-19. Ibadah daring dengan memanfaatkan kemajuan teknologi, membantu orang Kristen untuk beribadah dan bersekutu secara khusus bagi mereka yang ada di perkotaan. Jemaat rumah juga menjadi salah solusi untuk dapat tetap beribadah meskipun di tengah pandemi. Misi pekabaran Injil merupakan bagian dari gereja. Berkaitan dengan dengan pembatasan sosial, pelayanan misi pekabaran Injil juga merasakan dampak. Pelayanan misi dan pekabaran Injil tidak lepas dari interaksi sosial dengan orang lain. Pembatasan sosial tentuanya akan menjadi situasi yang sulit bagi pelayan misi untuk dapat berbagi kabar baik.

Jika gereja merespon pembatasan sosial ini dengan melakukan ibadah daring atau pun jemaat rumah, maka pelayan misi atau lembaga misi harus kreatif memikirkan cara ataupun strategi agar dapat bermisi, membagikan kabar baik kepada orang lain meskipun ada pembatasan sosial. Menjadikan semua bangsa

\footnotetext{
${ }^{3}$ Roedy Silitonga, "RESPON GEREJA ATAS PANDEMIK CORONA VIRUS DESEASE 2019 DAN IBADAH DI RUMAH," Manna Rafflesia 6, no. 2 (30 April 2020): 86-111, https://doi.org/10.38091/man_raf.v6i2.125.

${ }^{4}$ Wijaya dkk., "MENSTIMULASI PRAKTIK GEREJA RUMAH DI TENGAH PANDEMI COVID-19."
} 
murid Kristus merupakan Amanat Agung yang tidak dapat ditunda, apapun hambatannya. Sukardi menuliskan jika dalam waktu 24 jam Amanat Agung tidak ditaati, maka Amanat Agung tidak akan pernah ditaati. ${ }^{5}$ Oleh sebab itu, pembatasan sosial dalam konteks pandemi covid-19 tidak boleh menjadi penghalang untuk melaksanakan Amanat Agung. Fenomena ini menuntut kreativitas pelayan misi sebagai pemberita kabar baik untuk dapat menemukan sebuah strategi atau cara. Sebelum pandemi covid-19, model pelayanan misi dengan menggunakan media sosial telah dilakukan. Pasasa telah melakukan penelitian dengan topik pemanfaatan media internet dalam pemberitaan Injil. ${ }^{6}$ Namun penelitian ini belum spesifik menjelaskan mengenai jenis media yang digunakan. Selain itu, yes He is yang merupakan aplikasi buatan Indonesia juga telah memulai pelayanan misi daring sebelum masa pandemi.

Digitalisasi yang identik dengan media sosial merupakan salah satu cara yang dapat dimanfaatkan. Penelitian yang dilakukan oleh Hartono mengemukan bagaimana mengaktualisasikan Amanat Agung dalam era digital. ${ }^{7}$ Masa pandemi dibarengi dengan maraknya fenomena digitalisasi. Pelayanan misi daring, yakni dengan memanfaatkan media sosial dan sejenisnya telah dilakukan sebelum pandemi. Strategi ini layak dan perlu dikembangkan dimasa pandemi, agar Amanat Agung tetap dapat dilaksanakan meskipun dalam situasi pembatasan sosial.

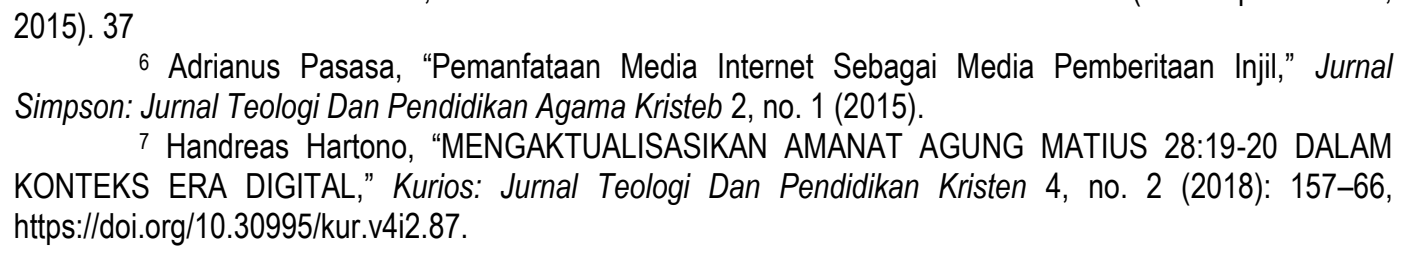
2015). 37

6 Adrianus Pasasa, "Pemanfataan Media Internet Sebagai Media Pemberitaan Injil," Jurnal Simpson: Jurnal Teologi Dan Pendidikan Agama Kristeb 2, no. 1 (2015).

7 Handreas Hartono, "MENGAKTUALISASIKAN AMANAT AGUNG MATIUS 28:19-20 DALAM KONTEKS ERA DIGITAL," Kurios: Jurnal Teologi Dan Pendidikan Kristen 4, no. 2 (2018): 157-66, https://doi.org/10.30995/kur.v4i2.87.

${ }^{5}$ Y.M Imanuel Sukardi, STRATEGI PENANAMAN GEREJA EKSPANSIONAL (STT Baptis Jakarta, 


\section{METODE}

Metode dan penulisan karya ilmiah tidak dapat dipisahkan dalam sebuah penelitian. Idealnya, peneliti yang baik, akan memikirkan dan menggunakan metode dalam penelitiannya untuk menemukan pembaharuan. Akan tetapi, sebelum menentukan metode yang digunakan dalam sebuah penelitian, perlu menetapkan topik penelitian agar dapat memutuskan metode yang digunakan. Penelitian ini, menggunakan metode kualitatif. Dengan pendekatan deskripsi analisis dan kajian pustaka. Menurut Nazir, metode deskriptif adalah metode yang digunakan untuk membuat gambaran mengenai situasi atau kejadian. ${ }^{8}$ Adapun strategi dalam penelitian ini yakni, dengan cara mengumpulakan datadata yang diperoleh dengan meneliti literatur-literatur yang berkaitan dengan topik, selain itu, data juga didapat dari pengamatan fenomena- fenomena yang sedang terjadi dan juga wawancara. Semua data yang diperoleh kemudian dianalisis dan selanjutnya dideskripsikan.

\section{HASIL}

Misi untuk menjadikan semua bangsa murid Kristus, merupakan mandat yang diberikan kepada setiap orang percaya melalui Amanat Agung. Apa pun hambatan yang ada, Amanat Agung harus tetap dilaksanakan sebagai mandat ilahi yang harus dituntaskan. Penelitian ini memaparkan mengenai tantangan pelayanan misi dalam menyampaikan kabar baik dimasa pandemi covid-19. Hasil dari penelitian ini memberikan jawaban bahwa dimasa pandemi covid-19 misi pekabaran injil tetap dapat dilakukan. Pandemi covid-19 menuntut kreativitas para pelayan misi agar dapat tetap melaksanakan Amanat Agung. Meskipun ada

8 Moh. Nazir, Mettode Penelitian (Bogor: Ghalia Indonesia, 2014). 43 
pembatasan interaksi sosial bukan berarti tidak dapat memberitakan kabar baik. Secara singkat, hasil dari penelitian ini dapat dijabarkan sebagai berikut, Pertama, penggunaan media sosial. Media sosial merupakan salah satu sarana yang dapat digunakan untuk memberitakan kabar baik di masa pandemi covid-19 dan diperlukan kreativitas dari pelayanan misi untuk mengerjakannya. Aplikasi yang termasuk dalam media sosial (facebook, YouTube, Instagram, Tiktok) adalah beberapa aplikasi media sosial yang dapat dimanfaatkan untuk pelyanan misi dimasa pandemi. Beny Santoso, telah memberikan pemaparan dalam penelitiannya mengenai pemanfaatan media sosial bagi penginjilan sebagai bentuk respon gereja dimasa pandemi. ${ }^{9}$ Jika pelayan misi kreatif memanfaatkan media, maka tugas menyelesaikan Amanat agung tetap dapat dilaksankan meskipun dimasa pandemi.

Kedua, pelayanan daring. pelayanan daring merupakan bentuk pelayanan keagamaan yang dilakukan selama masa pandemi covid-19 dalam bentuk ibadah virtual, atau dengan memanfaatkan jaringan internet. Sesungguhnya bentuk pelayanan ini pernah dilakukan pada masa sebelum pandemi yakni pekabaran Injil online atau daring.

\section{PEMBAHASAN}

Misi berasal dari istilah latin "missio" yang berarti mengutus. Kuyper sebagaimana dikutip oleh Enos, menjelsakan bahwa misi merupakan pelayanan yang dikaitkan dengan dengan pengutusan seseorang oleh Tuhan. ${ }^{10}$ Misi juga dapat didefinisikan sebagai pengutusan untuk memberitakan Injil. Misi

9 Benny Santoso, "Social Media Sebagai Sarana Penginjilan Respon gereja Masa Pandemic Covid-19," preprint (Open Science Framework, 12 Oktober 2020), https://doi.org/10.31219/osf.io/a9k86. 11

10 I Nyoman Enos, PENUNTUN PRAKTIS MISIOLOGI MODERN (Bandung: Kalam Hidup, 2012). 
merupakan bagian dari pelayanan gereja. Misi juga sering disebut sebagai motor bagi pertumbuhan gereja. Gereja yang bertumbuh secara kualitas, akan menunjukan ketaatan kepada Allah sebagai wujud mengasihi Allah. Ketaatan kepada Allah juga tercermin dalam menjalankan Amanat Agung, sehingga misi pekabaran Injil berjalan dengan baik. Pekabaran Injil gereja mula-mula berjalan dengan sangat baik. Alkitab mencatat pelipatgandaan jemaat yang luar biasa terjadi, dimulai dari 120 murid, bertambah 3000 dan selanjutnya terus bertambah. Misi juga dapat didefinisikan sebagai sebuah gerakan, bukan hanya sebatas pengutusan tetapi gerakan untuk memuridkan dan melipatgandakan. Sehingga misi dapat dipahami sebagai sebuah gerakan pengutusan untuk menjadikan setiap suku bangsa menjadi murid Kristus.

Menjadikan semua bangsa murid Kristus sebagaimana diamanatkan dalam Matius 28: 19-20 merupakan tugas dan tangung jawab orang percaya. Enos menulis bahwa pesan misi dari masa ke masa tetaplah sama, yang berubah hanyalah penerima pesan misi dalam berpikir dan bertindak. ${ }^{11}$ Oleh karena itu, dalam menjalankan misi pekabaran Injil diperlukan strategi. Purdaryanto menjelaskan pentingnya menentukan strategi untuk menyampaikan berita Injil sebagaimana telah dilakukan oleh rasul Paulus. ${ }^{12}$ Peristiwa ini dapat dilihat dalam Kisah Para Rasul 17: 16-34, ketika memberitakan Injil kepada orang Athena, Paulus menggunakan strategi misi kontekstual agar dapat memenangkan orang-orang Athena. Teks lainnya yang berkaitan dengan strategi Paulus dalam memberitakan Injil adalah dalam 1Korintus 9: 19-23, dimana Paulus

11 Enos. 9

12 Samuel Purdaryanto, "STRATEGI MELAYANI UNREACHED PEOPLE GROUPS BERDASARKAN KAJIAN EKSEGETIS 1KORINTUS 9: 19-23," Manna Rafflesia 6, no. 2 (30 April 2020): 178-99, https://doi.org/10.38091/man_raf.v6i2.122. 
menyesuaikan diri kepada kelompok yang dijangkaunya agar mereka dapat dimenangkan. Pandemi covid-19 menambah tantangan bagi pelayanan misi, kreativitas pelayan misi diperlukan untuk membuat strategi bagaimana melakukan pelayanan misi di masa pandemi covid-19.

\section{Pelayanan Daring}

Daring merupakan singkatan dalam jaringan yang merupakan terjemahan dari kata online. Istilah ini digunakan untuk menunjukan aktivitas yang dilakukan dengan menggunakan jaringan internet. Pada masa pandemi covid-19, pertemuanpertemuan daring menjadi solusi guna menghindari kerumunan yang menyebabkan penyebaran virus. Demikian halnya dengan kegiatan keagamaan, yang juga memanfaatkan internet untuk mengadakan pertemuan-pertemuan. Misalnya gereja, yang mengadakan kebaktian daring dan beberapa kegiatan lainnya yang diselenggarakan secara daring.

Model pelayanan ini merupakan bentuk respon gereja menghadapi situasi pandemi covid-19 untuk memastikan pembinaan rohani atas umat tetap dapat berjalan meski di tengah pandemi covid-19. Pelayanan daring menjadi solusi, untuk melayani jemaat dalam pelayanan lainnya misalnya konseling. Pemanfaatan media sosial sebagai sarana pelayanan gereja mungkin saja sangat solutif, meskipun hanya dapat dilakukan di wilayah-wilayah tertentu saja. Menurut Siahaan perkembangan dan kemajuan teknologi merupakan obyek bagi pelayanan. ${ }^{13}$ Oleh karena itu situasi pandemi covid-19 ini menjadi tantangan untuk lebih mengaktualisasikan dan mengembangkan pelayanan dengan

13 Harls Evan R. Siahaan, "Aktualisasi Pelayanan Karunia di Era Digital," EPIGRAPHE: Jurnal Teologi dan Pelayanan Kristiani 1, no. 1 (29 Januari 2018): 23, https://doi.org/10.33991/epigraphe.v1i1.7. 
memanfaatkan kemajuan teknologi. Pelayanan dan ibadah daring merupakan salah satu bentuk pemanfaatan kemajuan teknologi.

Pelayanan daring dan pemanfaatan media sosial tidak hanya terbatas pada pelayanan gerejawi saja seperti kebaktian raya ataupun kebaktian doa. Pemanfaatan media sosial secara daring ini juga dapat diimplementasikan dalam pelayanan misi pekabaran Injil. Sebagaimana telah disinggung di atas bahwa pembatasan sosial menyulitkan interaksi sosial atau tatap muka. Pelayanan misi pekabaran Injil, idealnya membutuhkan interaksi sosial dan pertemuan, namun pandemic covid-19 telah menghalangi hal itu. Pelayanan daring dan penggunaan media sosial dapat menjadi solusi bagi pelayanan misi pekabaran Injil.

\section{Media Sosial}

Media sosial merupakan produk dari kemajuan teknologi informatika. Prasetyo dan Trisyanti menuliskan revolusi industri 4.0 yang terjadi sekitar tahun 2010 melalui rekayasa intelegensia dan internet of thing sebagai tulang punggung pergerakan konektivitas manusia dan mesin, yang mengakibatkan perubahan manusia dalam berpikir dan berinteraksi. ${ }^{14}$ Jauh sebelum pandemi media sosial sudah menjadi tempat berinteraksi yang merupakan dampak perubahan prilaku manusia akibat revolusi industry 4.0. Sebagaimana dikutip oleh Santoso dalam Nasurullah menjelaskan bahwa media sosial merupakan kumpulan perangkat lunak yang memungkinkan individu atau pun kelompok untuk berkomunikasi, berinteraksi maupun berbagi informasi. ${ }^{15}$ Berikut ini adalah gambar data penggunaan media sosial yang dilansir dari situs kata data.

\footnotetext{
${ }^{14}$ Banu Prasetyo dan Umi Trisyanti, "REVOLUSI INDUSTRI 4.0 DAN TANTANGAN PERUBAHAN SOSIAL," IPTEK : Journal Of Proceedings Series, no. 5 (2018): 22-27, https://dx.doi.org/10.12962/j23546026.y2018i5.4417.

15 Santoso, "Social Media Sebagai Sarana Penginjilan Respon gereja Masa Pandemic Covid-19."
} 


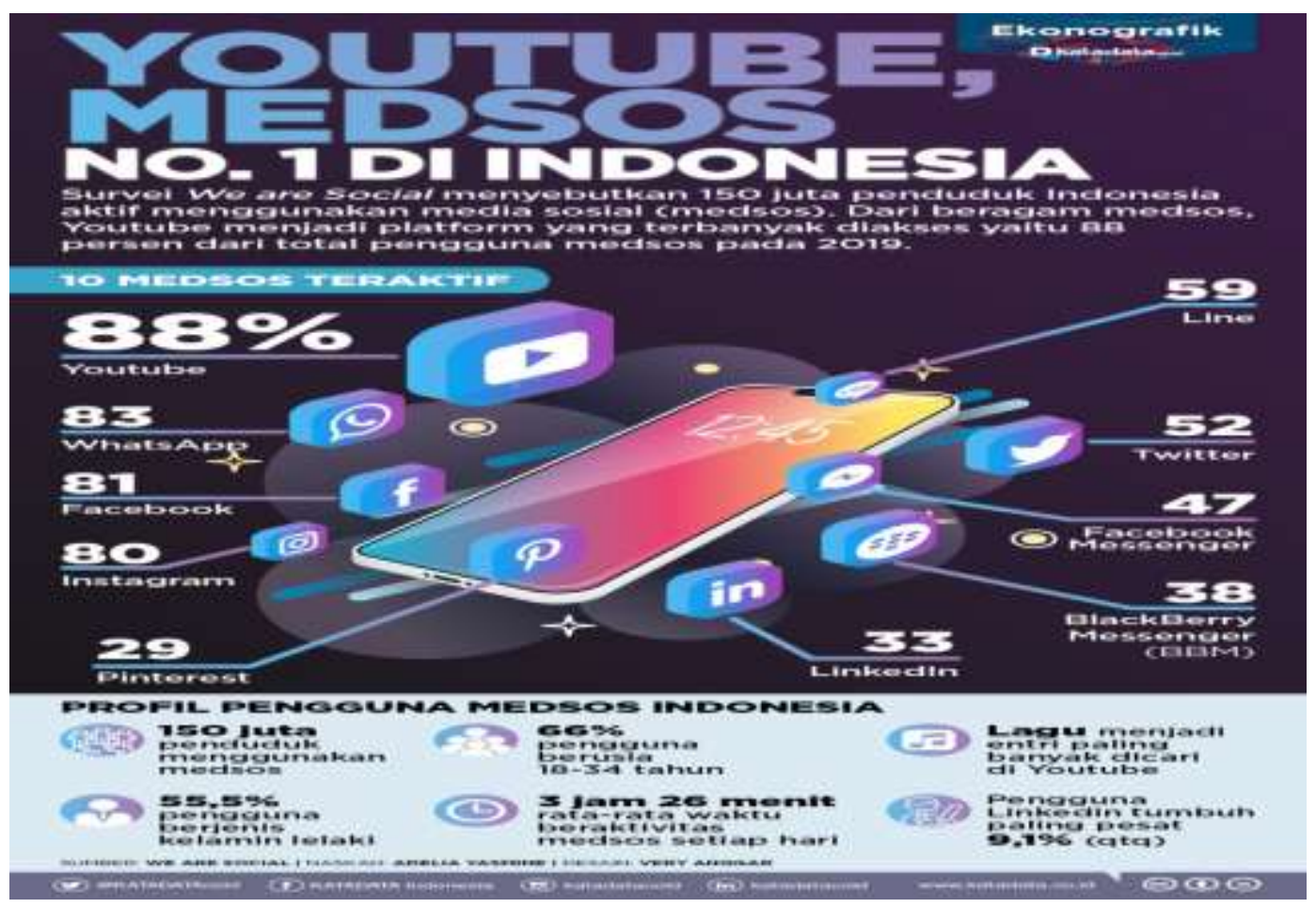

Sumber Gambar: Kata Data.

Melihat penjelasan di atas, sangatlah mungkin media sosial dapat menjadi solusi dalam pelayanan misi pekabaran Injil di tengah pembatasan sosial akibat pandemi covid-19. Sama halnya dengan ibadah daring, pekabaran Injil juga dapat dilakukan secara daring dengan memanfaatkan media sosial. Beberapa media sosial yang ada saat ini dapat dimanfaatkan menjadi sarana bagi pelayanan misi pekabaran Injil. Salah satu bentuk penginjilan daring adalah model penginjilan aplikasi "yes He is." Menurut Oktavianus, "yes He is" merupakan aplikasi lokal buatan orang Indonesia, yang menolong setiap orang Kristen untuk bermisi dengan cara menyediakan video kesaksian dan tulisan yang dapat dibagikan melalui jaringan internet. ${ }^{16}$ Aplikasi seperti "yes He is" sudah ada sebelum pandemi covid-19 dan memang memiliki visi dan tujuan untuk melakukan pelayanan misi pekabaran Injil secara daring. Pemanfaatan media sosial

16 Steaven Octavianus, "Analisis Penggunaan Aplikasi 'yesHeis' Dalam Penginjilan Pribadi," Evangelikal: Jurnal Teologi Injili dan Pembinaan Warga Jemaat 2, no. 1 (23 Februari 2018), https://doi.org/10.46445/ejti.v2i1.92. 
merupakan pilihan yang solutif dan tepat untuk pelayanan misi dalam konteks pandemi covid-19.

Aplikasi "yes He is" merupakan salah satu contoh media yang dapat digunakan sebagai sarana atau alat dalam pelayanan misi pekabaran Injil. Beberapa media sosial lainnya juga dapat dimanfaatkan sebagai alat dan sarana bagi pelayanan misi pekabaran Injil dalam konteks pandemi covid-19. Interaksi yang terjadi dalam media sosial menjadi jalan bagi pelayanan misi pekabaran Injil di tengah pembatasan sosial dan interaksi. Ada beberapa jenis media sosial lainnya yang dapat digunakan untuk berinteraksi sosial dan juga menjadi sarana pelayanan misi pekabaran Injil. Terkait dengan perkembangan media sosial, ada beberapa jenis media sosial yang digunakan untuk berinteraksi sosial atau berbagi informasi. Setidaknya ada 10 media sosial yang paling sering digunakan oleh orang Indonesia yakni; Facebook, Youtube, Whatsapp, Instagram, Twiter, Tiktok, Line, Reddit, Pinterest dan Tumblr. ${ }^{17}$ Setiap media sosial tersebut memiliki pengguna yang cukup banyak, dan tentunya memiliki kekurangan dan kelebihan masing-masing. Akan tetapi, pemabahasan dalam penelitian ini, tidak akan membahas semua media sosial tersebut dalam kaitanya sebagai saran pelayanan misi pekabaran Injil, namun hanya akan membahas beberapa saja yang memiliki banyak pengguna.

\section{Facebook}

Facebook merupakan media jejaring sosial yang cukup besar. Facebook didirikan tahun 2003 oleh Mark Zuckerberg dan teman- teman kuliahnya di Universitas Harvard. Awalnya media sosial ini bernama face mash dan kemudian

${ }_{17}$ Raka Fahreza Widyananda, "10 Macam Media Sosial yang Paling Sering Digunakan Oleh orang Indonesia," Merdeka, 4 Juni 2020, https://www.merdeka.com/jatim/10-macam-media-sosial-yang-palingsering-digunakan-oleh-orang-indonesia-kln.html. 
berganti nama menjadi facebook pada 4 februari 2004 dan menjadi salah satu perusahaan tekonologi besar selain Amazon, Apple dan Google. ${ }^{18}$ Aplikasi facebook memungkinkan pengguna untuk beriinteraksi dan bertukar informasi secara daring atau online. Data yang beredar, pengguna facebook diseluruh dunia tembus pada angka 2,7 milyar dan di Indonesia sendiri sekitar 130 juta pengguna.

Facebook sudah ada sejak 2004, dan merupakan tempat interaksi sosial, sharing informasi satu sama lain. Pembatasan sosial yang dilakuakan dalam rangka mencega penyebaran virus corona, membuat media sosial seperti facebook dimanfaatkan lebih jauh untuk berinteraksi bagi komunitas tertentu. Aplikasi ini juga memiliki fitur halaman yang dapat memuat cerita berupa tulisan dan videovideo. Dalam kaitannya bagi pelayanan misi pekabaran Injil, facebook juga dapat dimanfaatkan sebagai sarana untuk menyampaikan kabar baik bagi banyak orang dalam konteks pandemi covid-19. Dalam penggunaanya dibutuhkan kreativitas pelayanan misi untuk mengemas berita Injil sedemikian rupa.

Dalam wawancara dengan beberapa pelayan misi yang melayani di salah satu kabupaten di pulau Jawa, peneliti menanyakan bagaimana cara mengabarkan Injil dalam konteks pandemi covid-19, yang menuntut orang untuk tidak berinteraksi satu sama lain, bahkan berkerumun. Salah satu cara yang digunakan adalah dengan memanfaatkan media sosial facebook, yaitu dengan membuat halaman dan mengundang banyak orang pengguna facebook untuk menyukai halaman tersebut. ${ }^{19}$ Dalam halaman facebook tersebut tertulis kesaksisan bagaimana seorang mengenal Yesus. Selain itu, ada juga tulisan yang menjelaskan

18 Devita Retno, "Sejarah Berdirinya Facebook-Jejaring Sosial Besar," Teknologi/Sejarah Berdiringa Facebook (blog), t.t., https://sejarahlengkap.com/teknologi/sejarah-berdirinya-facebook. diakses 21 Februari 2021

19 HP Pamungkas, Memulai Gereja Rumah, 24 Januari 2021. 
peristiwa bagaimana manusia jatuh kedalam dosa dan bagaimana Tuhan Yesus mengampuni dosa manusia. fanpage atau halaman perlu dilengkapi dengan kontak pelayan agar dapat menerima respon dari pembaca untuk selanjutnya di-follow up.

Cara lain yang dapat digunakan untuk menyampaikan kabar baik melalui akun jejaring sosial facebook adalah dengan membuat video kesaksian dan membagikannya. Konten video dapat berupa kesaksian bagaimana situasi sebelum mengenal Yesus dan setelah menerima Yesus, atau bisa juga menyaksikan pertolongan Tuhan pada situasi-situasi yang sulit. Kreativitas seorang pelayanan misi dibutuhkan agar dapat menyajikan video kesaksian yang menarik, serta dapat menyampaikan pesan Injil. Membuat narasi berita Injil yang disajikan dalam bentuk tulisan mau pun video animasi juga dapat dilakukan melalui media ini. Sebagai contoh, peristiwa kejatuhan manusia ke dalam dosa dalam kitab Kejadian 3 hingga kepada pengorbanan dan kebangkitan Yesus yang dibuat dalam rangkaian cerita atau pun video. Harapannya setiap yang melihat ataupun membacanya dapat mengetahui berita Injil.

\section{Youtube}

YouTube menjadi salah satu media sosial yang popular dan disukai oleh masyarakat Indonesia. Sebuah situs yang berfungsi untuk berbagi video secara daring. YouTube didirikan oleh tiga orang mantan pekerja PayPal yakni, Steve Chen, Chad Hurley dan Jewed Karim pada Februari 2005, dan menjadi milik google pada Februari 2006. ${ }^{20}$ Pada umumnya YouTube digunakan oleh individu, akan tetapi tidak sedikit juga digunakan oleh lembaga penyiaran publik. Kelebihan dari media ini adalah memungkinkan penggunanya untuk mengakses

20 Feronika Azmil, "Sejarah Singkat YouTube, Situs Video Sharing Terbesar," Merdeka, 2 September 2013, https://www.merdeka.com/teknologi/sejarah-singkat-youtube-situs-video-sharing-terbesartekstory.html. 
video mau pun mengunggah dan membagikannya. Tidaklah heran aplikasi ini cenderung disukai oleh masyarakat.

Pengguna YouTube mengakses video dan berbagi video memiliki tujuan yang beraneka ragam. Kebanyakan mengakses video memiliki tujuan untuk mendapatkan informasi, misalnya seputar olahraga, tutorial dan lain sebaginya. Namun tidak sedikit juga yang hanya sekadar mencari hiburan dengan menyaksikan film pendek atau pun mendengarkan musik. Demikian juga pengguna yang berbagi video, umumnya isi video yang dibagikan berupa informasi, tutorial maupun hiburan. Sebagai informasi, penonton YouTube di Indonesia berjumlah kurang lebih 93 juta dengan usia di atas 18 tahun. $^{21}$

Dalam kaitannya dengan pelayanan misi pekabaran Injil, media ini juga dapat digunakan sebagai upaya atau strategi pelayanan misi dimasa pandemi covid-19. Pembatasan sosial dan aktivitas di rumah, menjadikan YouTube sebagai salah satu tontonan atau pun tempat membagikan video guna menghilangkan kepenatan. Melihat perkembangan selama pandemi covid-19, YouTube banyak digunakan untuk menyiarkan atau membagikan video yang berisi kegiatan gereja, seperti kebaktian, mau pun kegiatan sekolah minggu. Sehingga melalui video yang dibagikan siapa pun dapat menyaksikan. Dengan melihat perkembangan yang ada, YouTube juga dapat digunakan sebagai sarana dalam pelayanan misi pekabaran Injil. Dalam pelaksanaanya, memang diperlukan kreatifitas dan inovasi para pelayanan misi. Salah satu bentuk pelayanan misi pekabaran Injil dapat disaksikan di chanel YouTube "Kanuru." Chanel YouTube ini menampilkan video kesaksian pengalaman dari orang-orang yang telah mengenal Yesus Kristus dan

${ }_{21}$ Tesalonica Tesalonica, "Jumlah Pengguna Unik YouTube di Indonesia capa 93 juta," tek.id, 15 September 2020, https://www.tek.id/tek/jumlah-pengguna-unik-youtube-di-indonesia-capai-93-jutab1ZT79iPE. 
memutuskan untuk menjadi pengikut-Nya. Video kesaksian disajikan dalam bentuk talkshow dimana pemilik chanel YouTube melakukan Tanya jawab terhadap narasumber kesaksian. Menurut penuturan pengelola chanel YouTube "Kanuru", selama pelayanan misi menggunakan media ini mendapat respon yang cukup menarik, salah satunya adalah penonton yang memberikan respon dengan mengirim email untuk tahu lebih banyak tentang berita Injil. ${ }^{22}$ Email menjadi pilihan bagi pengelola chanel YouTube ini untuk merespon pilihan dan bahkan untuk mem-follow up orang-orang yang tertarik dengan berita Injil.

Harus diakui, selama masa pandemi covid-19 penonton YouTube meningkat. Pembatasan sosial dan gerakan di rumah saja diawal pandemi covid19 membuat masyarakat menjadikan YouTube sebagai salah satu pilihan untuk ditonton atau pun membagikan video. Menurut YB tidak sedikit juga penonton yang tertarik dengan hal-hal spiritual dan ingin mencari kebenaran untuk dijadikan pegangan hidup. ${ }^{23}$ Oleh karena itu, pemanfaat media YouTube sangatlah baik untuk pelayanan misi pekabaran Injil dan tentunya dibutuhkan kreativitas pelayanan misi untuk membuat video menarik yang berisi berita Injil.

\section{Instagram}

Media lainnya yang akan dibahas dalam kaitannya sebagai sarana dalam pelayanan misi pekabaran Injil adalah Instagram. Instagram pada awalnya adalah aplikasi tempat berbagi foto dan video yang memungkinakn penggguna untuk mengambil foto dan memfilternya. Nama instagram berasal dari kata 'instan' dan 'telegram' kata instan yang mendasari kata insta dengan makna ini instagram 
dapat mengambil foto secara cepat. ${ }^{24}$ Instagram yang merupakan aplikasi media sosial untuk berbagi foto kelihatannya kurang tepat jika digunakan sebagai saran untuk pelayanan misi pekabaran Injil. Barangkali, anggapan tersebut ada benarnya, namun juga kurang tepat.

Media ini juga dapat dimanfaatkan untuk digunkan sebagai sarana bagi pelayanan misi pekabaran Injil. Misalnya saja membagikan gambar yang berisi kutipan ayat firman Tuhan, atau mungkin semacam kalimat singkat yang mengarah pada berita Injil namun dalam bentuk foto. IGTV salah satu fitur dalam Instagram juga dapat dimanfaatkan untuk membuat video yang berdurasi 1,5 menit untuk mengenalkan Kekristenan yang berpusat pada Kristus. Video yang dimulai dari kisah penciptaan, kejatuhan manusia dalam dosa, pengorbanan Kristus, hingga kebangkitan Kristus.

Aplikasi instagram juga memungkinkan pengguna untuk melakukan live instagram bersama para pengikut akun atau pengguna lain. Dalam kaitannya bagi pelayanan misi, live instagram memungkinkan untuk berbagi pengalaman hidup, motivasi dan menceritakan bagaimana karya Tuhan dalam kehidupan orang percaya.

\section{Aplikasi Tiktok}

Tiktok termasuk media sosial yang digandrungi oleh remaja dan pemuda. Tiktok masuk dalam salah satu media sosila yang cukup memiliki banyak pengguna dimasa kini. Tiktok merupakan aplikasi jejaring sosial dimana penggunanya dapat membagikan video menyanyi dan lainnya. Apliakasi ini berasal dari Tiongkok yang diluncurkan sekitar awal September tahun 2016.

24 Anugerah Ayu Sendari, "Instagram Adalah Apliksi Berbagi Foto dan Video, Ini deretan Fitur canggihnya," Liputan6.com, 1 Maret 2019, https://www.liputan6.com/tekno/read/3906736/instagram-adalahplatform-berbagi-foto-dan-video-ini-deretan-fitur-canggihnya. 
Menurut sumber aplikasi ini dikembangkan oleh dua sahabat yakni Alex Zhu dan Luyu Yang dengan konsep yang baru. ${ }^{25}$ Aplikasi ini cukup menarik karena pengguna dapat bernyanyi, menari mengikuti panduan kemudia dibuat video pendek dan dibagikan. Sepanjang tahun 2018 hingga tahun 2019, aplikasi sudah diunduh sebanyak 48,5 juta kali.

Penelitian yang dilakukan oleh Aji dan Setyadi membahas tentang pemanfaatan tiktok sebagai media pembelajaran bersastra. ${ }^{26}$ Penelitian ini membahas bagaimana menggunakan tiktok dalam pembelajaran sastra dalam konteks digital. Akan tetapi, penelitian lainnya meneliti dari sudut pandang yang berbeda, yakni mengenai hubungan penggunaan tiktok dengan prilaku narsis remaja. $^{27}$ Melihat kepada kedua penelitian ini, tentunya akan menemukan kelebihan dan kekurangan dari aplikasi tersebut. Namun demikian, penelitian ini akan melihat hal postif aplikasi ini dan pemanfaatanya bagi pelayanan misi.

Pembatasan sosial dan interaksi sosial, menuntut inovasi bagi pelayan misi dalam pekabaran Injil. Media jejaring sosial seperti tiktok juga dapat dimanfaatkan sebagai sarana pekabaran Injil seperti halnya facebook, yotutube dan instagram. Melihat fitur yang tersedia pada aplikasi tiktok sangat memungkinkan aplikasi ini dugunakan sebagai media pelayanan misi pekabaran Injil. Aplikasi ini memungkinkan untuk mengunggah potongan video, misalnya saja potongan video film Yesus dalam versi Injil Lukas. Atau membuat kesaksian singkat menjadi Kristen dan bagaimana mengenal Kristus. Akhir-akhir ini ada banyak sekali

${ }^{25}$ Andry Winarto, "Sejarah dan Fakta Tentang Aplikasi Tiktok," tagar.id, 21 September 2020, https://www.tagar.id/sejarah-dan-fakta-tentang-aplikasi-tiktok.

26 Wisnu Nugroho Aji dan Dwi Bambang Putut Setiyadi, "APLIKASI TIK TOK SEBAGAI MEDIA PEMBELAJARAN KETERAMPILAN BERSASTRA," METAFORA: Jurnal Pembelajaran Bahasa Dan Sastra 6, no. 1 (2020): 147-57.

27 Devri Aprilian, Yessy Elita, dan Vira Afriyati, "Hubungan Antara Penggunaan Aplikasi Tiktok Dengan Perilaku Narsisme Siswa Kelas VIII Di SMP Negeri 8 Kota Bengkulu," Consilia: Jurnal IImiah Bimbingan dan Konseling 2, no. 3 (8 Januari 2020): 220-28, https://doi.org/10.33369/consilia.2.3.220-228. 
potongan khotbah dari seorang pengkhotbah wanita yang bertebaran di dunia maya melalui apilkasi Tiktok. Sebenarnya itu merupakan bentuk kreatifitas untuk berbagi kajian firman Tuhan kepada orang lain dan bentuk pemberitaan Injil secara daring. Konten-konten lain yang berkaitan dengan penyampain berita Injil juga dapat dibuat dan dibagikan.

\section{Analisis}

Amanat agung merupakan mandat yang harus dilaksanakan meskipun di tengah pandemi covid-19. Pembahasan di atas memberikan solusi bagaimana tetap dapat menunaikan tugas pelayanan misi pekabaran Injil dimasa pandemi covid19. Akan tetapi, penulis juga merasa perlu memberikan ulasan atau analisa berkaitan dengan strategi atau upaya pelayanan misi dpekabaran Injil di tengah pandemi covid-19.

Pelayanan misi pekabaran Injil dengan strategi daring memiliki kelebihan. Ada pun yang menjadi kelebihannya adalah bahwa pelayanan ini tidak dibatasi oleh pembatasan sosial sebagai akibat dari pandemi covid-19. Karena berita Injil tetap dapat disampaikan meskipun terjadi pembatasan sosial dan sulitnya berinteraksi terhadap sesama karena pencegahan covid-19. Ketika menemukan kekuatan dari pelayanan misi pekabaran Injil secara daring ini, perlu memperhatikan kelemahan dari bentuk pelayanan ini. Salah satu kelemahan dari pelayanan misi pekabaran Injil secara daring adalah kesulitan dalam mem-follow up. Ketika berita Injil disampaikan melalui media sosial, sulit untuk mendeteksi siapa yang mendengar dan menerima berita yang disampaikan. Salah satu cara yang digunakan untuk melihat respon dari pendengar atau penonton berita Injil yang disampaikan melalui media sosial yakni dengan memberikan atau 
mencantum alamat email atau nomer handphone. Hal ini juga diakui oleh YB Psa, pengelola chanel youtube "Kanuru" yang selalu berkomunikasi melalui email kepada penonton chanel YouTubenya untuk menindaklanjuti responnya. ${ }^{28}$ Kelemahan lainnya adalah jika penonton berasal dari tempat atau kota yang jauh dan sulit dijangkau sehingga tidak bisa melakukan follow up lanjutan.

Kendati demikian, peluang menggunakan media sosial sebagai saran untuk mengabarkan Injil masih sangat besar. Kemajuan teknologi, dan minat masayarakat akan teknologi digital merupakan peluang yang sangat besar untuk melayani mereka. Misalnya saja chanel youtube yang memiliki penonton di Indonesia hampir 93 juta. Sangat mengesankan, karena berpeluang menyampaikan berita Injil kepada 93 juta penonton meskipun tidak memastikan berapa orang yang sungguh-sungguh menonton. Budaya menggunakan media sosial dikalangan remaja dan pemuda juga menjadi kesempatan.

Analisis selanjutnya adalah hambatan dari pelayanan misi pekabaran Injil secara daring. Resiko merupakan bagian dari setiap tindakan yang diambil. Dalam konteks pekabaran Injil secara daring, sangat mungkin memiliki resiko yang lebih besar dari pada dengan cara bertemu langsung, namun bisa juga sebaliknya. Pamungkas menjelaskan bahwa timnya menggunakan fanpage facebook untuk berbagi informasi berita Injil tanpa menunjukan identitas. ${ }^{29}$ Akan tetapi sudah mempersiapkan diri jika ada resiko akibat dari tindakan dan kreativitasnya dalam memberitakan Injil. Hambatan lainnya adalah jaringan internet. Tidak semua tempat memiliki akses internet yang baik. Pelayanan misi pekabaran Injil cukup sulit menjangkau daerah pedesaan yang tidak ada jaringan internet, sehingga tetap 
membutuhkan perkunjungan. Kurangnya kreativitas pelayan misi dalam menggunakan media sosial juga termasuk dalam hambatan internal.

\section{KESIMPULAN}

Pandemi covid-19 telah melumpuhkan banyak aspek. Bukan hanya orang saja yang sakit terserang virus tersebut. Namun, ada banyak dampak yang ditimbulkan baik dalam ranah ekonomi, sosial dan lainnya. Pembatasan sosial guna mencegah penyebaran virus corona berdampak pada kegiatan keagamaan, termasuk pelayanan misi pekabaran Injil yang harus dilakukan dengan interaksi sosial dan tatap muka menemukan jalan buntu. Strategi dan kreativitas seoarang pelayanan misi sangat diperlukan. Penelitian ini menjelaskan bahwa masa pandemi covid-19, bukanlah halangan bagi orang percaya para pelayan misi pekabaran Injil untuk menuntaskan Amanat Agung. Persoalan pembatasan sosial untuk mencegah penularan Covid-19 bukanlah penghalang atau hambatan bagi pelayan misi pekabaran Injil. Pelayanan misi pekabaran Injil secara daring atau online, merupakan solusi atau jawaban. Pelayanan misi pekabaran Injil masih dapat dilaksanakan dengan memanfaatkan kemajuan teknologi yakni menggunakan media sosial. Beberapa aplikasi media sosial sebagaimana telah dijelaskan di atas dapat dimanfaatkan sebagai sarana pelayanan misi pekabaran Injil. Bagian yang paling penting adalah para pelayan misi harus melek teknologi dan membiasakan diri untuk menggunakan media sosial sebagai sarana pelayanan misi, serta mengembangkan kreativitas dari pelayan misi, untuk mengemas berita Injil agar dapat disampaikan melalui media sosial yang ada. Pelayanan misi pekabaran Injil daring adalah ladang misi baru. Kedepannya diperlukan penelitian 
lanjutan untuk melihat atau pun mengukur efektivitas pelayanan misi pekabaran injil secara daring.

\section{DAFTAR PUSTAKA}

Aida, Nur Rohmi. "Update Corona Dunia 14 Februari: 109 Juta Kasus Dunia." Kompas, https://www.kompas.com/tren/read/2021/02/14/083400665/update-coronadunia-14-februari--109-juta-kasus-covid-19-optimisme-boris?page=all.

Aji, Wisnu Nugroho, dan Dwi Bambang Putut Setiyadi. "Aplikasi Tik Tok Sebagai Media Pembelajaran Keterampilan Bersastra." Metafora: Jurnal Pembelajaran Bahasa Dan Sastra 6, no. 1 (2020): 147-57.

Aprilian, Devri, Yessy Elita, dan Vira Afriyati. "Hubungan Antara Penggunaan Aplikasi Tiktok Dengan Perilaku Narsisme Siswa Kelas VIII Di SMP Negeri 8 Kota Bengkulu." Consilia: Jurnal Ilmiah Bimbingan dan Konseling 2, no. 3 (8 Januari 2020): 220-28. https://doi.org/10.33369/consilia.2.3.220-228.

Azmil, Feronika. "Sejarah Singkat YouTube, Situs Video Sharing Terbesar." Merdeka. 2 September 2013. https://www.merdeka.com/teknologi/sejarahsingkat-youtube-situs-video-sharing-terbesar-tekstory.html.

Enos, I Nyoman. Penuntun Praktis Misiologi Modern. Bandung: Kalam Hidup, 2012.

Hartono, Handreas. "Mengaktualisasikan Amanat Agung Matius 28:19-20 Dalam Konteks Era Digital." Kurios: Jurnal Teologi Dan Pendidikan Kristen 4, no. 2 (2018): 157-66. https://doi.org/10.30995/kur.v4i2.87.

Nazir, Moh. Mettode Penelitian. Bogor: Ghalia Indonesia, 2014.

Octavianus, Steaven. “Analisis Penggunaan Aplikasi 'yesHeis' Dalam Penginjilan Pribadi." Evangelikal: Jurnal Teologi Injili dan Pembinaan Warga Jemaat 2, no. 1 (23 Februari 2018). https://doi.org/10.46445/ejti.v2i1.92.

Pamungkas, HP. Memulai Gereja Rumah, 24 Januari 2021.

Pasasa, Adrianus. "Pemanfataan Media Internet Sebagai Media Pemberitaan Injil." Jurnal Simpson: Jurnal Teologi Dan Pendidikan Agama Kristeb 2, no. 1 (2015).

Prasetyo, Banu, Dan Umi Trisyanti. "Revolusi Industri 4.0 Dan Tantangan Perubahan Sosial." Iptek : Journal Of Proceedings Series, no. 5 (2018): 22-27. https://dx.doi.org/10.12962/j23546026.y2018i5.4417. 
Psa, YB. Penggunaan YouTube Dalam Pelayanan, 23 Februari 2021.

Purdaryanto, Samuel. "Strategi Melayani Unreached People Groups Berdasarkan Kajian Eksegetis 1korintus 9: 19-23." Manna Rafflesia 6, no. 2 (30 April 2020): 178-99. https://doi.org/10.38091/man_raf.v6i2.122.

Retno, Devita. "Sejarah Berdirinya Facebook-Jejaring Sosial Besar." Teknologi/Sejarah Berdiringa Facebook (blog), t.t. https://sejarahlengkap.com/teknologi/sejarah-berdirinya-facebook.

Santoso, Benny. "Social Media Sebagai Sarana Penginjilan Respon gereja Masa Pandemic Covid-19." Preprint. Open Science Framework, 12 Oktober 2020. https://doi.org/10.31219/osf.io/a9k86.

Sendari, Anugerah Ayu. "Instagram Adalah Apliksi Berbagi Foto dan Video, Ini deretan Fitur canggihnya." Liputan6.com. 1 Maret 2019. https://www.liputan6.com/tekno/read/3906736/instagram-adalah-platformberbagi-foto-dan-video-ini-deretan-fitur-canggihnya.

Siahaan, Harls Evan R. "Aktualisasi Pelayanan Karunia di Era Digital." EPIGRAPHE: Jurnal Teologi dan Pelayanan Kristiani 1, no. 1 (29 Januari 2018): 23. https://doi.org/10.33991/epigraphe.v1i1.7.

Silitonga, Roedy. "Respon Gereja Atas Pandemik Corona Virus Desease 2019 Dan Ibadah Di Rumah.” Manna Rafflesia 6, no. 2 (30 April 2020): 86111. https://doi.org/10.38091/man_raf.v6i2.125.

Sukardi, Y.M Imanuel. Strategi Penanaman Gereja Ekspansional. STT Baptis Jakarta, 2015.

Tesalonica, Tesalonica. "Jumlah Pengguna Unik YouTube di Indonesia capa 93 juta." tek.id, 15 September 2020. https://www.tek.id/tek/jumlah-penggunaunik-youtube-di-indonesia-capai-93-juta-b1ZT79iPE.

Widyananda, Raka Fahreza. "10 Macam Media Sosial yang Paling Sering Digunakan Oleh orang Indonesia." Merdeka. 4 Juni 2020. https://www.merdeka.com/jatim/10-macam-media-sosial-yang-palingsering-digunakan-oleh-orang-indonesia-kln.html.

Wijaya, Fransiskus Irwan, Chandra Gunawa Marisi, T.Mangiring Tua Togatorop, Dan Handreas Hartono. "Menstimulasi Praktik Gereja Rumah Di Tengah Pandemi Covid-19." Kurios: Jurnal Teologi Dan Pendidikan Kristen 6, no. 1 (2020): 127-39. https://doi.org/10.30995/kur.v6i1.166.

Winarto, Andry. "Sejarah dan Fakta Tentang Aplikasi Tiktok." tagar.id. 21 September 2020. https://www.tagar.id/sejarah-dan-fakta-tentang-aplikasitiktok. 